Full reference: Alshbili, Ibrahem, and Elamer, Ahmed Ahmed, "The Vocational Skills Gap in Accounting Education Curricula: Empirical Evidence from the UK". International Journal of Management in Education. Forthcoming (Accepted $16^{\text {th }}$ April, 2019).

\title{
The Vocational Skills Gap in Accounting Education Curricula: Empirical Evidence from the UK
}

\author{
Ibrahem Alshbili \\ Consultant at the Libyan Audit Bureau \\ Email: abrhem200615@yahoo.com
}

\begin{abstract}
Ahmed A. Elamer *
Brunel Business School, Brunel University London, Kingston Lane, Uxbridge, London, UB8 3PH UK; and

Department of Accounting, Faculty of Commerce, Mansoura University, Mansoura, Egypt Email: ahmed.a.elamer@gmail.com

*Corresponding author
\end{abstract}

*Corresponding author: Brunel Business School, Brunel University London, Kingston Lane, London UB8 3PH, UK, E-mail: ahmed.elamer@brunel.ac.uk or/and ahmed.a.elamer@gmail.com. 


\title{
The Vocational Skills Gap in Accounting Education Curricula: Empirical Evidence from the UK
}

\begin{abstract}
This paper aims to investigate the relative importance of a set of vocational skills and the extent to which accounting educators in the UK incorporate these skills into their accounting education curricula so that students can run a successful accounting career upon their graduation. Using a questionnaire method, the data was collected from two major stakeholders; namely accounting educators and final-year accounting students. The findings indicate that there is a degree of overall agreement between the two groups opinions' that vocational skills required by accounting employers encompass not only technical and cognitive skills but also transferable skills such as communication, self-reflection, teamwork and organisational skills. The results of this paper should be of interest to accounting educators, curriculum designers and faculty who are responsible for reviewing and updating accounting curricula.
\end{abstract}

Keywords Vocational skills; accounting education curricula; accounting educators; accounting students; UK 


\section{Introduction}

Since the 1980s, the accounting education curriculum has seen many debates and criticisms in terms of what should be included in its contents and whether those contents are considered to fill the rising gap between theory and practice (Kotb et al., 2013; Olazaran et al., 2018). Among these debates and criticisms, calls have been raised to include the development of competence of vocational skills in accounting education curricula such as communication skills, team working skills, problem-solving skills, information technology skills and other related skills (Bui and Porter 2015). Broadly speaking, in today's business environment, undoubtedly changes in business are occurring swiftly and employers' opinions regarding accountants have already outlined the need to build up a wide variety of vocational skills. Evidence put forward by several studies (e.g. Birrell et al., 2006; Hassall et al., 2005; Rubin and Dierdorff, 2009) pointed out that the education of accountants is in the spotlight with many concerns such as: "course content and curricula, the delivery or teaching approach, factually selection and the staff's knowledge and the ability to offer real-world guidance, a vocational versus academic focus, the employability and readiness of graduates, students' exposure to technology and its application in business, and most importantly the rigour and relevance of curricula in today's complex business environment" (De Villiers, 2010, p.1).

Indeed, a report by Albrecht and Sack (2000) states that accounting educational modules continue to have too limited a focus on skills development in the curricula. This debate is also being reported by employers who are demanding a variety of skills and attributes in new accounting graduates to sustain an economical benefit in the work environment (Birrell et al., 2006). Specifically, the major point arising among the curricula of accounting is the emphasis placed on the need to prepare students sufficiently for future roles in the accounting field through developing vocational skills during their degree. Undeniably, vocational skills are very important and have been the subject of interest to researchers (e.g. De Villiers, 2010; Jones, 2010) who focused on studying the generic skills in the accounting education profile, and to the accounting professional bodies such as the Chartered Institution of Management Accountants (CIMA) who focused on vocational skills in the management accounting profile (Hassall et al., 2005; Montano et al., 2001). Consequently, 
accounting educators, students and employers consider vocational skills as important and necessary for a successful career in accounting, and therefore, it is important that accounting schools prepare students to fulfil the future needs of employers, by making closer contact with those who represent the future work environment that needs to be developed. However, despite the interest in the vocational skills from the employers' perspective and owing to the fact that the list of what professional skills are needed in graduates and what they should possess to be employable (they are already well documented in the literature), this research will examine only the vocational skills from the accounting educators and third-year accounting students' opinions.

\section{Literature review}

\subsection{The accounting education and its syllabus developments}

While the CPAA and ICAA (2005) have drawn up warning signals regarding the future of accounting education. Lin (2008) concluded that most of the accounting educators and accounting practitioners agree that the existing accounting education should be reformed. In such a case, Cheng (2007) suggested that accounting education should be changed from "supply driven to demand driven". Along the same lines, Albrecht and Sack (2000) argued that a debate and criticism is still being raised by both employers and accounting educators about accounting programmes and it is believed that relying heavily on lectures can be a hindrance to acquiring vocational skills because they require the need to memorise and utilise knowledge and therefore vocational skills that are useful for the work place are replaced by materials that are less useful. Daigle et al. (2007) also argued that accounting programmes at universities generally remain to face pressure from work environment and businesses to determine 'accountability' for outcomes.

Furthermore, Jackson et al. (2012) pointed out that there is a need to reform accounting education to meet the requirements of the external environment, by taking into account the rising demand for the variety of vocational skills that are essential in the accounting field, Braun (2004) also emphasises that accounting educators worldwide are being urged to alter the curriculum to produce accounting graduates with a broader set of skills and attributes encompassing more than purely technical accounting expertise. De Lange et al. (2006) came up with a conclusion that accounting 
graduates' in fact, absence of readiness for the accounting work environment. Thus, this suggests that accounting curricula have failed to remain relevant to students and employers.

\subsection{The calls for change}

Indeed, the last two decades has witnessed the global financial crisis, a credit crunch, a European debt crisis, and several high-profile corporate failures, such as Enron, WorldCom, Northern Rock and RBS (Adhikariparajul et al., 2019; Alnabsha et al., 2018; Alshbili et al., 2019; Elamer et al., 2017, 2018, 2019; Elamer \& Benyazid, 2018; Elmagrhi et al., 2019). There are many change calls made by several researchers for accounting and/or business education to include a wide range of vocational skills to react to a rapidly changing business environment (Alhalwaki and Hamdan, 2019; Alkhyeli and Ewijk, 2018; Alo et al., 2018; Mkumbo, 2017; Prado and García, 2017; Saqipi, 2019). For example, Mathews (1990) indicates that a more comprehensive range of skills during students' degrees at universities should be developed so that they can successfully respond to the workplace needs. A similar claim is made by Coetzee and Oberholzer (2009) who concluded that in South Africa, the current education system may not be delivering "competent-chartered accountants" and graduates with the transferable acquired knowledge and skills to respond to the workplace. Additionally, Howieson (2003, p. 90) warned that "accounting is in danger of becoming a second class citizen relative to other business majors because these alternative fields of study appear to reflect changing business practices”. Along similar lines, Kavanagh and Drennan (2008) also pointed out that there is increased pressure placed on accounting graduates to demonstrate additional competencies to develop broader non-accounting skills and be committed to progressive skills improvement.

The call for change to include vocational skills into the accounting curricula is also being considered by professional bodies such as CIMA. According to Russell et al. (1999), the work ethic, analytical/problem-solving skills, interpersonal skills, and listening skills should be the most important attributes of a corporate accountant. Furthermore, in the UK, a study of CIMA employers' requirements by Montano et al. (2001) found that time management skills and communication skills are the most highly valued skills by employers. Furthermore, a similar study conducted by Hassall et al. (2003) regarding the vocational skills gap for management accountants, 
the stakeholders perspective", found similar results to his that communication skills and time management are the most imperative skills according to employers, however students did rank time management and information technology as the top significant skills. Furthermore, the Institute of Chartered Accountants of New Zealand (ICANZ) has highlighted that chartered accountants need to improve a varied variety of competencies such as understanding (e.g. content), skills (e.g. analytical, personal, technical, organizational, and interpersonal) and specialised values (e.g. moral behaviour). A similar need made by the accounting professional bodies in Australia who acknowledged the significance of the development of vocational skills for accounting graduates". The IFAC (2002) was also hinted for change by stating that the finance director role is changing radically from one of "transaction manager" to that of "communicator and schemer" and thus in order to be able to run these new roles successfully, very strong communication skills for future finance managers is a crucial

Accounting educators also support the view of calls for a change in accounting education to include these vocational skills. For example, in a study conducted by May et al. (1996), asking accounting educators about the changes needed in accounting education, found that $90.7 \%$ agreed that the accounting curriculum should contain a syllabus on communication skills, $86 \%$ supported the idea of a need for better emphasis on intellectual skills, and $77.8 \%$ agreed that interpersonal skills should have more emphasis. From graduates perspective, according to (Kavanagh and Drennan, 2008, p. 291) graduate students generally "felt that there was not enough emphasis placed on the skills they perceived as being necessary to their career in the programmes that were delivered". Additionally, the single skill for which the emphasis on students' studies came close to match their demands was "written communication" skills. However, in the same study, unfortunately, the fundamental skills that are not covered to the expected levels to students are; specialized attitude, self-motivation, oral communication, decision making and nonstop learning which are important to achieve the overall success of seeking accounting career. Furthermore, accounting software skills, customer service, motivation and negotiation, was also recorded to be the biggest gap between expectation and delivery.

However, despite these calls for change, some of the literature pointed out that accounting degree at university is just a basic preparation for employment in the accounting profession. For example, 
Tempone and Martin (2003, p. 3) argue that "there is sometimes a tendency within universities to maintain what is there and to add on additional subjects, tasks and content". Hutchinson and Fleischman (2003, p. 1) observed that "Most modern degree programs provide the opportunity for accounting students to develop oral, written and interpersonal communication skills as well as exposure to organisational skills and technology". Consequently, Celik and Ecer (2009) suggested that tutors should consider changing the courses and education methods in a way that would develop the vocational skills of accountants. Despite this, in response to such issues, some countries have already started to revise their education system such as Spain and the UK. According to Hassall et al. (2005, p. 1) "The higher education systems in Spain and the UK are being revised to improve the quality of education and to reduce the expectations gap relating to employer demands". This view can be confirmed by Bridgstock (2009) who claimed that universities have started to emphasis on developing vocational skills in accounting curricula so that students can get advantages of such skills which then might make them attractive to several employers across multiple work environments.

\subsection{Skills required in accountant graduates}

Deppe (1991) highlights that communication skills, information and distribution skills, decisionmaking skills, leadership and management skills must be developed among accounting education curricula. Stowers and White (1999) came up with a similar conclusion, that presentation skills, writing skills, interpersonal skills, listening and interviewing are essential skills among professional accountants. Along the same lines, Albrecht and Sack (2000) state that accounting educators and specialists agreed on which skills are significant that accountants should possess, and they identified that written communication, analytical/critical thinking and oral communication should be the most significant items to be given attention among accounting curricula. Along similar lines, Tempone and Martin (2003) also identified the need for communication skills, analytical and problem-solving skills among accounting curricula, because such skills are certainly expected by the accounting profession organisation, and are important tools in interpreting both financial and non-financial data within a business context. The requirements of such vocational skills are also highlighted by Tan and Veal (2005) in New Zealand 
indicating that accounting educators and practitioners expect trainee accountants to be excellent communicators, problem solvers and critical thinkers.

Furthermore, the evidence put forward by Kavanagh and Drennan (2008) have highlighted the future skills that accounting is likely to need, by concluding that these skills include: communication skills, personal and interpersonal skills, problem-solving and team work skills. An American report by Robert Half International regarding Next Generation Accountant, concluded that "To succeed in tomorrow's accounting, finance and audit environments, council members said professionals need a wider range of skills than at any time in recent memory. Well-developed financial and technical abilities remain essential, but strong interpersonal and analytical skills are increasingly crucial for success". As such, Lin (2008) observed that accountants should be able to and should have various skills to contract with diverse requirements for information processing such as good interpersonal skills, leadership skills, business promotion and negotiation skills, time management and ability to possess analytical skills. Therefore, the importance of vocational skills is being raised, perhaps due to the nature of accounting which has changed as a result of globalisation, technological advancements and changes in the economic landscape environment, which requires an accountant to have such skills rather than just basic numerical skills. This review suggests that there is a necessity for more focused skills to contract with the rising difficulty and regulatory, corporate governance and ethical issues impacting on the accounting profession.

\section{Method}

The sample was composed by 48 Accounting degree students in the last course of the degree $\left(3^{\text {rd }}\right.$ or/and $4^{\text {th }}$ ) and 8 accounting educators from a UK University. Specifically, the total number of accounting educators sampled was 15. A total number of 8 responses were received. This study also was aiming to target 80 third-year accounting students; however, 13 students denied to response to the questionnaire due to their time pressures. Thus, the total number of third-year accounting students sampled was 67. Of the 67 questionnaires distributed, a total number of 48 responses were received and 19 were not returned. The number of valid responses from those 48 responses, was 41 of which 7 responses were considered unusable, due to the fact that the questionnaire was incomplete, giving a response rate of $61.19 \%$. 
In order to gather and explore to what extent accounting educators within UK universities incorporate the vocational skills sets into their accounting education curricula, the questionnaire method was used. This questionnaire was based on a vocational skills sets survey developed by Hassall et al. (2003). The reason behind choosing this questionnaire is, it contained the skills that are the center of attention among the debate in the literature and because they do act as key important fundamental skills in the accounting education sector and employer groups such as firms. A five-point rating scale was used and it was structured as follows. In the first section, respondents were asked to rate the importance of each skill on a five-point scale from $1=$ unimportant to $5=$ very important on a list of 22 vocational skills set, divided into six skills sets: communication skills set (5 items), team working skills set (3 items), problem-solving skills set (4 items), time management skills set (3 items), information technology skills set ( 2 items) and others related skills, value and knowledge (5 items) set. The second section contained opinion-based questions which also asked accounting educators (the level of incorporation of the former six skills sets) and the third-year accountings students (the perceived level of the former six skills sets) to answer the same set of skills (the former 22 items) on a five-point scale from $1=$ strongly disagree to $5=$ strongly agree. The third section was about broad accounting curriculum policy which consisted of eight statements that were designed to obtain responses on the respondents' attitudes to overall syllabus development. The eight statements of the questionnaire were answered by asking accounting educators and third-year accounting students to indicate their agreement on a five-point scale from $1=$ strongly disagree to $5=$ strongly agree on specific statements about the development of such skills. The final section contained questions consisting of personal information about the respondents that include: gender, age. Also, in this section, respondents were asked to answer by (Yes) or (No) whether they have been on placement, and if so whether they worked in a relevant position that is related to their study. This questionnaire was sent to two distinct groups namely accounting educators and third year accounting students.

\section{Findings}

The total number of accounting educators sampled was 15. A total number of 8 responses were received. The figure of valid replies from those accounting educators was 7, providing a reply 
percentage of $46.67 \%$. The gender balance within this sample was $42.90 \%$ male and $57.10 \%$ female. The age of the accounting educators who responded to this survey were all above 31 years. This study was hoping to target 80 third-year accounting students; however, 13 students denied to response to the questionnaire due to their time pressures. Thus, the total number of third-year accounting students sampled was 67 . Of the 67 questionnaires distributed, a total number of 48 responses were received and 19 were not returned. The number of valid responses from those 48 responses, was 41 of which 7 responses were considered unusable, due to the fact that the questionnaire was incomplete, giving a response rate of $61.19 \%$. The gender balance of those students was 39\% female and 61\% male. Those student ages who answered this questionnaire ranged from 18 to 31 years and above, of which $53.70 \%$ were between 18 and 21 years, $34.10 \%$ were between 22 and 25 years, $9.80 \%$ were between 26 and 30 years, and $2.40 \%$ were 31 years and over. In terms of placement, the third-year accounting students were asked in the questionnaire whether they had been on placement, and if so, whether they did work in the area that is related to their studies. $26.80 \%$ (or 11) out of 41 students who responded to the questionnaire indicated that they had been on a placement and all of them worked in the area that is related to their studies i.e. Accounting and Finance. However, the rest of third-year accounting students' respondents i.e. $73.20 \%$ went directly to their final year.

\subsection{The accounting educators and the third-year accounting students mean scores for the importance of vocational skills.}

The mean scores, standard deviation and the ranking of vocational skills reported by the accounting educators as well as the third-year accounting students for the significance of every single skill of the specified 22 skills are presented in Table 1. The mean scores show that the accounting educators and third year accounting students thought every single one of the indicated "vocational skills" to be of significance for seeking a fruitful accounting career. The means of the scores stated by the accounting educators variety from 4.71 to 3.29 and have a total mean of 4.06. From Table 1, it can be noted that the accounting educators placed a strong focus on time management skills set and problem-solving skills set by giving them the highest scores. However, surprisingly the majority of "communication skills" set items and "other skills, values and knowledge" skills set were not 
highly valued by accounting educators (three of the five specified skills from each of those skills set are below the overall mean i.e. 4.06).

\section{INSERT TABLE 1 ABOUT HERE}

It is essential to know that there is a dissimilarity in emphasis between the accounting educators and the third-year accounting students in relation to the final ranking of the significance of detailed "vocational skills". The specific occupational abilities that "predominate" in the view of the accounting educators are those from time management and problem-solving skills sets, however, the third-year accounting students placed emphasis only on two skills.

\section{INSERT TABLE 2 ABOUT HERE}

\subsection{Skill level incorporated by the accounting educators and the perceptions skill level by the third-year accounting students}

The overall scores in Table 3 indicate that accounting educators and the third-year accounting students acknowledge that accounting curricula' have all the vocational skills sets. This can be realized from the high scores specified in Table 3 to all the listed 22 vocational skills. However, the most incorporated skills according to the accounting educators' opinion are problem solving skills set in which all items i.e. "Find creative solutions", "Identify and solve unstructured problems", "Integrate multidisciplinary knowledge to solve problems", "Perform critical analysis" 
scored the highest ranking. Overall, the vocational skills that are integrated into the accounting syllabus by accounting educators were problem solving skills set, other skills, values and knowledge skills set, team working skills set, communication skills set, information technology skills set and time management skills set.

In spite of the level of agreement between both the accounting educators and the third-year accounting students that all the six group skills sets consisting of 22 listed vocational skills are incorporated in the accounting curricula, there is an opinion gap between what accounting educators incorporated and what accounting students perceived. The gap in the first three skills in the communication skills set indicate that accounting educators incorporated these skills more than what third-year accounting students perceived, however, those students indicated a higher level of skills perceived in the last two items in this category.

\section{INSERT TABLE 3 ABOUT HERE}

Table 4 shows that the accounting educator prioritize problem solving skills set i.e. "Find creative solutions", "Identify and solve unstructured problems", "Integrate multidisciplinary knowledge to solve problems" and "Perform critical analysis" as well as one skill from team working skills set i.e. "Work with others in teams" as the first and second skills to be incorporated into the accounting curricula (as opposed to the respective third-year accounting students).

\section{INSERT TABLE 4 ABOUT HERE}

\subsection{Accounting educators and third-year accounting student answers to statements on “vocational skills" improvement}


Table 5 indicates that the accounting educators and the third-year accounting students did not share the same opinion that there is a necessity for accounting students who prepare to work in the professional area of accounting to improve "vocational skills". The accounting educators and the third-year accounting students both come to a similar agreement that the incorporation of vocational skills improvement and practical accounting awareness is appropriate.

\section{INSERT TABLE 5 ABOUT HERE}

\subsection{Comparison between placement and none-placement third-year accounting students regarding the importance of vocational skills}

In order to find out if there were any differences in terms of the importance of vocational skills sets between placement and none-placement third-year accounting students, the mean for each set of the six skills set was calculated, then two measures of the shape of the distribution were typically looked at.

\section{INSERT TABLE 6 ABOUT HERE}

Table 6 indicates that the value of problem-solving skills set (-0.46), time management skills set (0.25 ) and information technology skills set $(0.61)$, are between +1 and -1 , therefore, this indicates that such variables were normally distributed. However, based on the above table and with regard to Kurtosis measure, it can be seen that the value of the communication skills set (5.30), team working skills set (0.88) and other value, knowledge and skills set. (3.66) are between +3 and -3 , thus, this indicates that such variables were not normally distributed.

\subsection{Independent sample t-test and Mann-Whitney U Test}


Based upon the above explanation i.e. Skewness and Kurtosis measures explanation, and due to the fact that some variables were normally distributed and some others were not normally distributed, two tests were carried out. One test was used for the sample that is found "to be normally" distributed i.e. independent-sample t-test. The second test was used for the sample that is found to be "not normally" distributed i.e. Mann-Whiteny U Test. Independent sample t-test was used for "problem solving skills" set, "time management skills" set and "information technology skills" set, as they found to be normally distributed. Thus, Independent sample t-test provided two results i.e. mean scores and Independent sample t-test sig. value see Table 7 and 8 respectively below:

\section{INSERT TABLE 7 ABOUT HERE}

Table 7, with regard to the problem-solving skills set, third-year accounting students who went straight to their final year had a slightly higher mean rank than those who went on placement, which means that they tended to have higher value for such skills. However, this is not the case with regard to time management skills set, where third-year accounting students who went directly to their final year had a considerably lower mean rank than those who went on placement, which means that those who went on placement tended to value such skills as being higher. With regard to information technology skills set, accounting students who went straight to their final year had a marginally higher mean rank than those who went on placement, which means that they tended to have a higher value for such skills. Thus, in spite of the differences in the overall mean, it is important to consider if there are any significant differences. In effect, the details are provided in the following Table 8.

\section{INSERT TABLE 8 ABOUT HERE}


Table 8 demonstrates that there are no significant differences (at the 5\% level) between the accounting students who went on placement and those who went straight to their final year. For the problem-solving skills set. However, Table 8 reveals that there is no significant difference (at the $5 \%$ level) between the accounting students who went on placement and those who went straight to their final year. For the time management skills set. With regard to information technology skills set, Table 8 shows that there are no significant differences (at the 5\% level) between the accounting students who have on placement year and those who have gone straight to their final year. For the information technology skills set.

\subsection{Mann-Whitney U Test}

Since the assumption of variables i.e. communication skills set, team working skills set and other knowledge, value and skills set, were found not to be a normally distributed and to provide more information about if there is differences in the opinion between the third-year accounting students who went on placement and those who went directly to their third-year, the results of the MannWhitney $U$ Test are shown in Tables 9 and 10 respectively.

\section{INSERT TABLE 9 ABOUT HERE}

In the above table and with regard to g communication skills set, third-year accounting students who went directly to their final year had a slightly higher mean rank than those who went on placement, which means that they tended to have higher value for such skill. However, this is not the case with team working skills set. With regard to other values, knowledge and skills set, thirdyear accounting students who went on placement had a considerably higher mean than those who went straight to their final year. However, in spite of such differences in the mean, it is important to consider if there are any significant differences. In effect, Table 10 below provides the Sig. value for those skills. Table 10 shows that there are no significant differences in the importance of skills 
levels between the third-year accounting students who went on placement and those students who went straight to their final year (at the $\% 5$ level of significance).

INSERT TABLE 10 ABOUT HERE

\section{Discussion}

This study has aimed to highlight whether accounting educators at UK Universities incorporate the vocational skills sets (i.e. communication skills, team working skills, problem-solving skills, information technology skills, time management skills and some other skills, values and knowledge) into their accounting curricula. The findings indicate that in terms of the importance, the overall mean score for both groups i.e. accounting educators and the third-year accounting students, ranked all the skills of high valued suggesting that the all 22 listed skills in Table 1 are important. Such findings are strengthened when looking at Table 1, showing the lowest mean of importance among these skills to be 3.29 by accounting educators and lowest mean of 3.17 by the third-year accounting students. Overall in terms of the importance, the accounting educators' scores showed that they thought that time management and problem solving sets were the most important skills, followed by communication skills, team working skills, information technology skills, and other value, knowledge and skills sets, whilst the third-year accounting students thought it was mixed of team working, time management and communication skills sets as being the most important skills followed by problem solving, information technology and other value, knowledge and skills. These findings can be supported by the Oliver study (2008 p.1) which documented that "the attributes for success in commencing and advancing in a career and being an effective global citizen are communication, teamwork, problem solving, self-management, planning and organising, technology, life-long learning, initiative, enterprise and the raft of skills generally called emotional intelligence". With regard to third year accounting students, they ranked, "Critically read written works, making judgments on their relevance and value" as the most 
important skills from the communication skill set category. Such findings can be supported by DeLange et al. (2006) who concluded that communication skills are considered to be the most important skill for accounting graduates to possess in seeking a future career. However, despite of the importance of the information technology skills, in this study both groups ranked it in terms of the importance as a little bit lower than other skills set. Perhaps to both groups, the priorities for the other skills are more important. In this sense, Bui, et al. (2010) stated that the employers from all of the accounting companies assume that accounting graduates would rather have a comprehensive knowledge of accounting values and ideas, a simple understanding of business, and decent teamwork, communication, and interpersonal skills rather than advanced information technology skills.

With regard to the incorporation of the vocational skills into the accounting education curricula by the accounting educators and the perceptions levels of these skills by the third-year accounting students, this study found that there is a degree of overall agreement between the two groups opinions' that are all the six group skills set e.g. communication skills, team working skills. are being sufficiently incorporated by the accounting educators and sufficiently perceived by the thirdyear accounting students in the accounting curricula. The most incorporated skills according to the accounting educators' opinion are problem solving skills set followed by team working skills set, communication skills set, other values, knowledge and skills, information technology skills and time management skills set. These findings can be packed up by Bridgstock, (2009) view, who claimed that universities have started to emphasis on developing vocational skills in accounting education curricula so that students can get advantages of such skills which then might make them attractive to several employers across multiple work environments. With regard to third-year accounting students' opinions, they ranked one of the five vocational skills from the "Communication skills" set i.e. "Critically read written works, making judgments on their relevance and value" as being the most perceived skill in the accounting curricula respectively followed in order by "Work with others in teams" from team working skills set and "Knowledge of information sources" from information technology skills set. Such ranking can be supported by Kavanagh and Drennan (2008) who found that the single skill for which the emphasis in students' studies came close to match their demands was "written communication" skills. The overall 
findings of this study from students' opinion indicated that these vocational skills are perceived in their accounting curricula. However, such findings are different from Kavanagh and Drennan, (2008) findings who indicated that students themselves feel that the vocational skills that are essential to their career in accounting are not being sufficiently emphasised in their undergraduate accounting courses. Overall, the vocational skills in this study are found to be sufficiently incorporated into the accounting curricula. Perhaps the view that was put forward by Meyers et al., (2007) that the necessity for more focused skills essential to contract with the rise difficulty and regulatory, corporate governance and ethical issues impacting on the accounting profession have been taken into account. In addition, the overall findings of this study indicated that accounting educators have recognized the importance of incorporating these vocational skills, thus indicating that such accounting curricula appropriate. These findings can be supported by Hutchinson and Fleischman (2003, p. 1) who observed that "Most modern degree programs provide the opportunity for accounting students to develop oral, written and interpersonal communication skills as well as exposure to organisational skills and technology".

With regard to the developments of these skills into the accounting curricula, surprisingly the accounting educators and the third-year accounting students did not agree on the statement that "Accountants only need technical knowledge to successfully perform accounting duties". Here accounting educators disagreed to such statement whereas third-year accounting students agreed. Furthermore, both groups agreed that universities should integrate work-based necessities once planning new accounting curriculums. Both groups show a desired for incorporating vocational skills into all topic areas in the accounting syllabus and thought it as thinkable, however, the accounting educators slightly agreed to the need for additional specific courses to develop such skills as opposite to the third-year accounting students where they thought such development can be better achieved by extra detailed courses. Their interpretation of the significance of "vocational skills" is supported by their agreement that "in the personnel selection process, vocational skills are given at least the same value as accounting knowledge”. Such findings can be supported by Celik and Ecer (2009) views who suggested that tutors should consider changing the courses and education methods in a way that would develop the vocational skills of accountants. With regard if there were any differences between third-year accounting students' opinion who went straight 
to their final year and those who went on placement in terms of the importance of the six skills set (i.e. communication skills, group working skills, problem-solving skills, information technology skills, time management skills and some other skills, values and knowledge), two tests i.e. Independent-sample t-test and Mann-Whiteny U Test were carried out. In spite of there is a mean difference on the importance of the former skills between both groups answers i.e. third-year accounting students who went straight to their final year and those who went on placement, there is not a statistically significant differences in the importance of all six skills sets levels.

\section{Conclusion}

This study was conducted primarily to ascertain to what extent accounting educators at UK universities incorporate the vocational skills sets (i.e. communication skills, team working skills, problem-solving skills, information technology skills, time management skills and some other skills, values and knowledge) into their accounting curricula. The accounting educators and the third-year accounting students were all in agreement of the importance of these skills to seek a successful future accounting career. However, the rank orders of these vocational skills were slightly dissimilar. The accounting educators thought that time management skills set and problemsolving skills set were the most important skills; whilst the third-year accounting students thought it was a mix of some items from the team working skills set, time management skills set and communication skills set.

The other set of skills identified as having importance by the accounting educators were communication skills set, team working skills set, information technology skills set and other value, knowledge and skills set. The third-year accounting students identified respectively that problem solving skills set, information technology skills set and other value, knowledge and skills set as of importance. A degree of agreement was also highlighted between the accounting educators and the third-year accounting students in terms of the importance of the top ten rankings skills (see Table 2). Seven of the top ten rankings from the six skills sets were identified by both groups to be

of importance. Thus, a clear message from the accounting educators was highlighted by identifying that their main concern is to incorporate time management skills set into their accounting curricula. This is then followed by the acknowledged necessity to improve problem solving skill set. 
However, the third-year accounting students are slightly less clear about this significance as they identified the area of team working skills set as their key "priority" of importance followed by communication skills set.

With regard to the incorporation and the perceptions level of vocational skills in the accounting curricula, there is a degree of an overall agreement between both groups that all former six skills sets were incorporated and perceived sufficiently. The most incorporated skills according to the accounting educators' opinion are problem solving skills set followed by team working skills set in which two out of three skills were highly ranked i.e. "Work with others in teams" and "Assume leadership positions when necessary" followed by communication skills set in which four out of five skills were ranked highly incorporated into the curricula. However, the time management skills set that was classified previously by the accounting educators as being the most significant for an accountant to possess is not seen highly perceived by the third-year accounting students. The thirdyear accounting students perceived one skill from the "Communication skills" set i.e. "Critically read written works, making judgments on their relevance and value" as being the most incorporated skill in the accounting curricula respectively followed in order by "Work with others in teams" from team working skills set and "Knowledge of information sources" from information technology skills set. A comparison of the relevant highest ranks of vocational skills by both groups presented in table 4 shows that seven out of the highest ten skills that are incorporated by the accounting educators in the accounting education curricula are also perceived by the third-year accounting students to be of importance.

With regard to the development of eight statements of vocational skills in the accounting curricula, both the accounting educators and the third-year accounting students agreed that universities should incorporate work-based requirements and vocational skills into the accounting curricula when designing new syllabi. Their opinion of the significance of occupational skills is confirmed by their answer of the agreement that "in the personnel selection process, vocational skills are given at least the same value as accounting knowledge". However, surprisingly, the results further indicated that there is a level of disagreements about the statement that "Accountants only need technical knowledge to successfully perform accounting duties" as third-year accounting students agreed with the statement. With regard if there were any differences in the opinion between third- 
year accounting students who went on placement and those who went straight to their final year in terms of the importance for the all six skills sets, (i.e. communication skills, team working skills), the results indicated that there was not a statistically significant difference in the importance of these skills levels between both groups despite of the slight differences in their mean.

To conclude, in answering the question one of this research, which is "What vocational skills are incorporated into the accounting curriculum by accounting educators in the accountancy departments", it is clear from the analysis of the results and findings that the skills that were incorporated are in order: problem solving skills set, team working skills set, communication skills set, other skills, values and knowledge set, information technology skills set and time management skills set. With regard to the second question which is, "Does the current accountancy curriculum provide adequate coverage of appropriate vocational skills to its students", it is clear from the analysis of the opinions of the two main stakeholders in the accounting education that accounting educators do incorporate adequate coverage of these vocational skills into their accounting curricula and the third-year accounting students perceived these skills sufficiently. However, the baggiest gap of what accounting educator provide and what third year accounting students perceived is shown in the problem-solving skills set, though it was not a statistically significance. With regard to the third question of the research i.e. "Are there any differences of opinion regarding the importance of vocational skills between placement and non-placement students in third-year accounting students", the results show that there is not a statistically significant differences in the importance of all six skills sets between both groups. 


\section{References}

Adhikariparajul, M., Hassan, A., Fletcher, M., \& Elamer, A. A. (2019). Integrated reporting in UK higher education institutions. Sustainability Accounting, Management and Policy Journal, Forthcoming. https://doi.org/10.1108/SAMPJ-03-2018-0093

Albrecht, W. S., and Sack, R. J. (2000). Accounting education: charting the course through a perilous future. Accountig Education Series, Vol 16.

Alhalwaki, H., and Hamdan, A. M. M. (2019). Factors affecting the implementation of internationalisation strategies in higher education institutions: evidence from Bahrain. International Journal of Management in Education, Vol. 13, No. 1, pp. 1-27.

Alkhyeli, H. E., and Ewijk, A. Van. (2018). Prioritisation of factors influencing teachers' job satisfaction in the UAE. International Journal of Management in Education, Vol. 12, No. 1, pp. 1-24.

Alnabsha, A., Abdou, H. A., Ntim, C. G., \& Elamer, A. A. (2018). Corporate boards, ownership structures and corporate disclosures : Evidence from a developing country. Journal of Applied Accounting Research, Vol. 19, No. 1, pp. 20-41.

Alo, E., Slinn, H., Saqipi, B., and Vogrinc, J. (2018). Effective teacher professional development in the process of major school reforms. International Journal of Management in Education, Vol. 12, No. 2, pp. 114-131.

Alshbili, I., Elamer, A. A., \& Beddewela, E. (2019). Ownership types, corporate governance and corporate social responsibility disclosures: Empirical evidence from a developing country. Accounting Research Journal, Forthcoming. https://doi.org/10.1108/ARJ-03-2018-0060

Birrell, R., Hawthorne, L., Richardson, S., and Birrell, B. (2006). Evaluation of the general skilled migration categories: Department of Immigration and Multicultural Affairs Canberra, Australia.

Braun, N. M. (2004). Critical thinking in the business curriculum. Journal of Education for Business, Vol. 79, No. 4, pp. $232-236$

Bridgstock, R. (2009). The graduate attributes we've overlooked: Enhancing graduate employability through career management skills. Higher Education Research and Development, Vol. 28, No. 1, pp. 31-44.

Bui, B and Porter, B (2010). The Expectation-Performance Gap in Accounting Education: An Exploratory Study, Journal Accounting Education Vol. 19, No 1-2, pp. 23-50

Celik, O., and Ecer, A. (2009). Efficiency in accounting education: evidence from Turkish Universities. Critical Perspectives on Accounting, Vol. 20, No 5, pp. 614-634.

Cheng, K.-W. (2007). The curriculum design in universities from the perspective of providers in accounting education. Education, Vol. 127, No. 4, pp. 581-590.

Coetzee, S., and Oberholzer, R. (2009). The Tax Knowledge of South African Trainee Accountants: A Survey of the Perceptions of Training Officers in Public Practice. Accounting Education, Vol. 18, No. 4, pp. 421-441.

CPAA, C. P. A. A., and ICAA, I. o. C. A. i. A. (2005). Accreditation Guidelines for Universities Retrieved 23/05/2016 http://www.cpacareers.com.au/uploads/pdfs/accreditation_guidelines.pdf

Daigle, R. J., Hayes, D. C., and Hughes, K. (2007). Assessing student learning outcomes in the introductory accounting information systems course using the AICPA's core competency framework. Journal of Information Systems, Vol. 21, No. 1, pp. 149-169.

De Lange, P., Jackling, B., and Gut, A. M. (2006). Accounting graduates' perceptions of skills emphasis in undergraduate courses: an investigation from two Victorian universities. Accounting and Finance, Vol. 46, No. 3, pp 365-386.

De Villiers, R. (2010). The incorporation of soft skills into accounting curricula: preparing accounting graduates for their unpredictable futures. Meditari Accountancy Research, Vol. 18, No. 2, pp. 1-22.

Deppe, L. A. (1991). Emerging Competencies for the Practice of Accountancy. Journal of Accounting Education, Vol. 9, pp. 257-290.

Elamer, A. A., \& Benyazid, I. (2018). The impact of risk committee on financial performance of UK financial institutions. International Journal of Accounting and Finance, Vol. 8, No. 2, pp. 161-180.

Elamer, A. A., AlHares, A., Ntim, C. G., \& Benyazid, I. (2018). The corporate governance-risk-taking nexus: evidence from insurance companies. International Journal of Ethics and Systems, Vol. 34, No. 4, pp.493-509.

Elamer, A. A., Ntim, C. G., \& Abdou, H. A. (2017). Islamic governance, national governance, and bank risk management and disclosure in MENA countries. Business \& Society, Doi: 10.1177/0007650317746108. 
Elamer, A. A., Ntim, C. G., Abdou, H. A., Zalata, A., \& Elmagrhi, M. H. (2019). The impact of multi-layer governance on bank risk disclosure in emerging markets: The case of Middle East and North Africa. Accounting Forum, Forthcoming. https://doi.org/10.1080/01559982.2019.1576577

Elmagrhi, M. H., Ntim, C. G., Elamer, A. A., \& Zhang, Q. (2019). A study of environmental policies and regulations, governance structures and environmental performance: The role of female directors. Business Strategy and the Environment, 28(1), 206-220.

Hassall, T., Joyce, J., Arquero Montano, J. L., and Donoso Anes, J. A. (2003). The vocational skills gap for management accountants: the stakeholders' perspectives. Innovations in Education and Teaching International, Vol. 40, No. 1, pp. 78-88.

Hassall, T., Joyce, J., Montaño, J. L. A., and Anes, J. A. D. (2005). Priorities for the development of vocational skills in management accountants: A European perspective. Accounting Forum. Vol. 29, No. 4, pp. 379-394

Howieson, B. (2003). Accounting practice in the new millennium: is accounting education ready to meet the challenge? The British Accounting Review, Vol. 35, No. 2, pp. 69-103.

IFAC, I. F. o. A. (2002). The Role of the Chief Financial Officer in 2010, A Global Debate on Preparing Accountants for Finance Leadership.

Jackson, M., Watty, K., Yu, L., and Lowe, L. (2012). Inclusive assessment: improving learning for all: a manual for improving assessment in accounting education. Melboune, Vic.: ALTC

Jones, A. (2010). Generic attributes in accounting: the significance of the disciplinary context. Accounting Education: An International Journal, Vol. 19, No. 1-2, pp. 5-21.

Kavanagh, M. H., and Drennan, L. (2008). What skills and attributes does an accounting graduate need? Evidence from student perceptions and employer expectations. Accounting and Finance, Vol. 48, No. 2, pp. 279-300.

Lin, Z. J. (2008). A factor analysis on knowledge and skill components of accounting education: Chinese case. Advances in Accounting, Vol. 24, No. 1, pp. 110-118.

Mathews, R. L. (1990). Accounting in higher education : report of the Review of the Accounting Discipline in Higher Education. Australia: Canberra : Australian Govt. Pub. Service.

May, G. S., Windal, F. W., and Sylvestre, J. (1996). The need for change in accounting education: an educator survey. Journal of Accounting Education, Vol. 13, No 1, pp. 21-43.

Mkumbo, K. (2017). The effectiveness of the new education and training policy in addressing the learning crisis in Tanzania. International Journal of Management in Education, Vol. 11, No. 3, pp. 347-366.

Montano, J. L. A., Donoso, J. A., Hassall, T., and Joyce, J. (2001). Vocational skills in the accounting professional profile: the Chartered Institute of Management Accountants (CIMA) employers' opinion. Accounting Education, Vol. 10, No. 3, pp. 299-313.

Olazaran, M., Albizu, E., Otero, B., and Lavía, C. (2018). Vocational education-industry linkages: intensity of relationships and firms' assessment. Studies in Higher Education, Forthcoming. Doi: 10.1080/03075079.2018.1496411

Prado, M. M., and García, K. G. (2017). Organisational change in higher education institutions: a case study on restructuring the School of Social and Humanistic Sciences. International Journal of Management in Education, Vol. 11, No. 4, pp. 405-423.

Rubin, R. S., and Dierdorff, E. C. (2009). How relevant is the MBA? Assessing the alignment of required curricula and required managerial competencies. Academy of Management Learning and Education, Vol. 8, No 2, pp. 208-224.

Russell, K. A., Siegel, G. H., and Kulesza, C. (1999). Counting more, counting less. Strategic Finance, Vol. 81, No. 3,38 .

Saqipi, B. (2019). Teacher education policy discourse in the midst of system reorganisation and policy transfer: lessons for small and developing countries. International Journal of Management in Education, Vol. 13, No. 1, pp. 28-39.

Stowers, R. H., and White, G. T. (1999). Connecting accounting and communication: A survey of public accounting firms. Business Communication Quarterly, Vol. 62, No. 2, pp. 23-40.

Tan, L. M., and Veal, J. (2005). Tax Knowledge for Undergraduate Accounting Majors: Conceptual v. Technical. Journal of Tax Research, Vol. 3, No. 1, pp. 28-44.

Tempone, I., and Martin, E. (2003). Iteration between theory and practice as a pathway to developing generic skills in accounting. Accounting Education, Vol. 12, No. 3, pp. 227-244. 


\section{Tables}

Table 1: Accounting educators and third-year students mean scores for the importance of the vocational skills

\begin{tabular}{|c|c|c|c|c|c|c|}
\hline \multirow[t]{2}{*}{ Communication skills set } & \multicolumn{3}{|c|}{ Accounting educators } & \multicolumn{3}{|c|}{ Accounting students } \\
\hline & Mean & Rank & $\begin{array}{l}\text { Std. } \\
\text { Deviation }\end{array}$ & Mean & $\begin{array}{l}\text { Ran } \\
\mathbf{k}\end{array}$ & $\begin{array}{l}\text { Std. } \\
\text { Deviation }\end{array}$ \\
\hline $\begin{array}{l}\text { Allow students/you to present and defend points of view } \\
\text { and outcomes of work, in writing, to peers and staff. }\end{array}$ & 3.86 & $=14$ & 1.35 & 3.68 & 18 & 0.79 \\
\hline $\begin{array}{l}\text { Allow students/you to present and defend points of view } \\
\text { and outcomes of work, verbally, to peers and staff. }\end{array}$ & 3.86 & $=14$ & 1.46 & 3.78 & 14 & 0.69 \\
\hline Use of visual aids in presentations. & 3.43 & $=20$ & 1.51 & 3.49 & 20 & 0.84 \\
\hline $\begin{array}{l}\text { Listen effectively to gain information and to understand } \\
\text { opposing points of view. }\end{array}$ & 4.29 & $=7$ & 0.76 & 3.93 & 6 & 1.03 \\
\hline $\begin{array}{l}\text { Critically read written works, making judgments on their } \\
\text { relevance and value. }\end{array}$ & 4.14 & $=11$ & 1.46 & 4.15 & 1 & 0.91 \\
\hline \multicolumn{7}{|l|}{ Team working skills set } \\
\hline Work with others in teams. & 4.00 & 13 & 0.82 & 4.02 & $=3$ & 0.96 \\
\hline Organize and delegate tasks. & 3.71 & $=16$ & 1.25 & 3.95 & 5 & 1.05 \\
\hline Assume leadership positions when necessary. & 3.71 & $=16$ & 1.38 & 3.73 & $=15$ & 1.00 \\
\hline \multicolumn{7}{|l|}{ Problem-solving skills set } \\
\hline Identify and solve unstructured problems. & 4.43 & $=4$ & 0.79 & 3.80 & $=10$ & 0.87 \\
\hline Find creative solutions. & 4.29 & $=7$ & 0.76 & 3.80 & $=10$ & 0.90 \\
\hline $\begin{array}{l}\text { Integrate multidisciplinary knowledge to solve } \\
\text { problems. }\end{array}$ & 4.43 & $=4$ & 0.79 & 3.73 & $=15$ & 0.81 \\
\hline Perform critical analysis & 4.71 & $=1$ & 0.49 & 3.88 & $=7$ & 0.98 \\
\hline \multicolumn{7}{|l|}{ Time management skills set } \\
\hline $\begin{array}{l}\text { Organize the workloads to meet conflicting } \\
\text { demands and unexpected requirements. }\end{array}$ & 4.71 & $=1$ & 0.49 & 3.73 & $=15$ & 1.05 \\
\hline $\begin{array}{l}\text { Organize the workloads to recognize and meet } \\
\text { tight, strict, and coinciding deadlines. }\end{array}$ & 4.71 & $=1$ & 0.49 & 4.05 & 2 & 0.84 \\
\hline $\begin{array}{l}\text { Select and assign priorities within coincident } \\
\text { workloads. }\end{array}$ & 4.43 & $=4$ & 0.53 & 3.88 & $=7$ & 0.87 \\
\hline \multicolumn{7}{|l|}{ Information technology skills set } \\
\hline Use of accounting software. & 3.57 & 19 & 1.27 & 3.17 & 22 & 1.22 \\
\hline Knowledge of information sources. & 4.29 & $=7$ & 0.76 & 3.80 & $=10$ & 0.75 \\
\hline \multicolumn{7}{|l|}{ Other skills, values and knowledge set } \\
\hline Have a commitment to life-long learning. & 4.14 & $=11$ & 0.69 & 3.39 & 21 & 0.70 \\
\hline Ability to develop methods of effective learning. & 4.29 & $=7$ & 0.49 & 3.61 & 19 & 0.86 \\
\hline Awareness of social and ethical responsibilities. & 3.71 & $=16$ & 0.49 & 3.85 & 9 & 0.73 \\
\hline Have knowledge of the accounting profession. & 3.43 & $=20$ & 0.79 & 4.02 & $=3$ & 0.88 \\
\hline $\begin{array}{l}\text { Have a comprehensive and global vision of } \\
\text { organization. }\end{array}$ & 3.29 & 22 & 0.76 & 3.80 & $=10$ & 1.01 \\
\hline Overall mean & 4.06 & & & 3.78 & & \\
\hline
\end{tabular}


Table 2: Comparison of rankings of importance scores by accounting educators and third year accounting students

\begin{tabular}{|l|l|l|}
\hline & $\begin{array}{l}\text { Accounting } \\
\text { educators }\end{array}$ & $\begin{array}{l}\text { Third-year accounting } \\
\text { students }\end{array}$ \\
\hline Perform critical analysis & $=1$ & $=7$ \\
\hline $\begin{array}{l}\text { Organize the workloads to meet conflicting demands and } \\
\text { unexpected requirements. }\end{array}$ & $=1$ & $=15$ \\
\hline $\begin{array}{l}\text { Organize the workloads to recognize and meet tight, strict, and } \\
\text { coinciding deadlines. }\end{array}$ & $=1$ & 2 \\
\hline Identify and solve unstructured problems & $=4$ & $=10$ \\
\hline Integrate multidisciplinary knowledge to solve problems. & $=4$ & $=15$ \\
\hline Select and assign priorities within coincident workloads. & $=4$ & $=7$ \\
\hline Find creative solutions. & $=7$ & $=10$ \\
\hline Knowledge of information sources. & $=7$ & $=10$ \\
\hline Ability to develop methods of effective learning. & $=7$ & 19 \\
\hline $\begin{array}{l}\text { Listen effectively to gain information and to understand opposing } \\
\text { points of view. }\end{array}$ & $=7$ & 6 \\
\hline
\end{tabular}


Table 3: Skill level incorporated by the accounting educators and the perceptions skill level by the third-year accounting students

\begin{tabular}{|c|c|c|c|c|c|c|c|}
\hline \multirow[t]{2}{*}{ Communication skills set } & \multicolumn{3}{|c|}{ Accounting educators } & \multicolumn{4}{|c|}{ Third-year accounting students } \\
\hline & Mean & Rank & $\begin{array}{l}\text { Std. } \\
\text { Deviation }\end{array}$ & Mean & Rank & $\begin{array}{l}\text { Std. } \\
\text { Deviation }\end{array}$ & $\begin{array}{l}\text { Gap } \\
\text { score }\end{array}$ \\
\hline $\begin{array}{l}\text { Allow students/you to present and defend points of } \\
\text { view and outcomes of work, in writing, to peers and } \\
\text { staff. }\end{array}$ & 3.86 & $=8$ & 1.35 & 3.49 & 21 & 0.84 & 0.37 \\
\hline $\begin{array}{l}\text { Allow students/you to present and defend points of } \\
\text { view and outcomes of work, verbally, to peers and } \\
\text { staff. }\end{array}$ & 3.86 & $=8$ & 1.49 & 3.56 & $=16$ & 0.81 & 0.30 \\
\hline Use of visual aids in presentations. & 3.57 & $=18$ & 1.40 & 3.56 & $=16$ & 0.78 & 0.01 \\
\hline $\begin{array}{l}\text { Listen effectively to gain information and to } \\
\text { understand opposing points of view. }\end{array}$ & 3.86 & $=8$ & 1.35 & 3.88 & $=4$ & 0.68 & -0.02 \\
\hline $\begin{array}{l}\text { Critically read written works, making judgments on } \\
\text { their relevance and value. }\end{array}$ & 3.86 & $=8$ & 1.35 & 3.93 & $=1$ & 0.72 & -0.07 \\
\hline \multicolumn{8}{|l|}{ Team working skills set } \\
\hline Work with others in teams. & 4.29 & $=2$ & 1.11 & 3.90 & $=2$ & 0.83 & 0.38 \\
\hline Organize and delegate tasks. & 3.71 & $=15$ & 1.38 & 3.88 & $=4$ & 0.75 & -0.16 \\
\hline Assume leadership positions when necessary. & 3.86 & $=8$ & 1.35 & 3.85 & $=8$ & 0.82 & 0.01 \\
\hline \multicolumn{8}{|l|}{ Problem-solving skills set } \\
\hline Identify and solve unstructured problems. & 4.29 & $=2$ & 0.95 & 3.66 & $=11$ & 0.85 & 0.63 \\
\hline Find creative solutions. & 4.43 & 1 & 0.53 & 3.51 & 20 & 0.81 & 0.92 \\
\hline $\begin{array}{l}\text { Integrate multidisciplinary knowledge to solve } \\
\text { problems. }\end{array}$ & 4.29 & $=2$ & 0.76 & 3.59 & 15 & 0.84 & 0.70 \\
\hline Perform critical analysis & 4.29 & $=2$ & 0.76 & 3.88 & $=4$ & 1.10 & 0.41 \\
\hline \multicolumn{8}{|l|}{ Time management skills set } \\
\hline $\begin{array}{l}\text { Organize the workloads to meet conflicting demands } \\
\text { and unexpected requirements. }\end{array}$ & 3.71 & $=15$ & 0.76 & 3.54 & $=18$ & 1.03 & 0.18 \\
\hline $\begin{array}{l}\text { Organize the workloads to recognize and meet tight, } \\
\text { strict, and coinciding deadlines. }\end{array}$ & 3.71 & $=15$ & 0.76 & 3.85 & $=8$ & 0.91 & -0.14 \\
\hline $\begin{array}{l}\text { Select and assign priorities within coincident } \\
\text { workloads. }\end{array}$ & 3.00 & 22 & 0.58 & 3.66 & $=11$ & 0.99 & -0.66 \\
\hline \multicolumn{8}{|l|}{ Information technology skills set } \\
\hline Use of accounting software. & 3.57 & $=18$ & 1.40 & 3.32 & 22 & 1.15 & 0.25 \\
\hline Knowledge of information sources. & 3.86 & $=8$ & 0.90 & 3.90 & $=2$ & 0.83 & -0.05 \\
\hline \multicolumn{8}{|l|}{ Other skills, values and knowledge set } \\
\hline Have a commitment to life-long learning. & 3.86 & $=8$ & 1.07 & 3.54 & $=18$ & 0.74 & 0.32 \\
\hline Ability to develop methods of effective learning. & 4.00 & 7 & 0.82 & 3.73 & 10 & 0.71 & 0.27 \\
\hline Awareness of social and ethical responsibilities. & 3.43 & 21 & 0.53 & 3.66 & $=11$ & 0.88 & -0.23 \\
\hline Have knowledge of the accounting profession. & 4.14 & 6 & 0.69 & 3.88 & $=4$ & 0.84 & 0.26 \\
\hline $\begin{array}{l}\text { Have a comprehensive and global vision of } \\
\text { organization. }\end{array}$ & 3.57 & $=18$ & 0.79 & 3.66 & $=11$ & 1.02 & -0.09 \\
\hline Overall mean & 4.04 & & & 3.86 & & & \\
\hline
\end{tabular}


Table 4: Comparison of the rankings of skill level scores incorporated by accounting educators and the skill level scores perceived by the third-year accounting students

\begin{tabular}{|l|l|l|}
\hline & Accounting educators & $\begin{array}{l}\text { Third-year } \\
\text { students }\end{array}$ \\
\hline Find creative solutions. & 1 & 20 \\
\hline Work with others in teams & $=2$ & $=2$ \\
\hline Identify and solve unstructured problems. & $=2$ & $=11$ \\
\hline $\begin{array}{l}\text { Integrate multidisciplinary knowledge to solve } \\
\text { problems. }\end{array}$ & $=2$ & 15 \\
\hline Perform critical analysis & $=2$ & $=4$ \\
\hline Have knowledge of the accounting profession. & 6 & $=4$ \\
\hline $\begin{array}{l}\text { Ability to develop methods of effective } \\
\text { learning. }\end{array}$ & 7 & $=4$ \\
\hline $\begin{array}{l}\text { Critically read written works, making } \\
\text { judgments on their relevance and value. }\end{array}$ & $=8$ & 1 \\
\hline $\begin{array}{l}\text { Listen effectively to gain information and to } \\
\text { understand opposing points of view. }\end{array}$ & $=8$ & $=4$ \\
\hline $\begin{array}{l}\text { Allow students/you to present and defend } \\
\text { points of view and outcomes of work, in } \\
\text { writing, to peers and staff. }\end{array}$ & $=8$ & 21 \\
\hline Knowledge of information sources. & $=8$ & $=2$ \\
\hline
\end{tabular}


Table 5: Accounting educators and third-year accounting student answers to statements on "vocational skills" development

\begin{tabular}{|l|r|l|}
\hline & Accounting educators & $\begin{array}{l}\text { Third-year } \\
\text { accounting students }\end{array}$ \\
\hline $\begin{array}{l}\text { Accountants only need technical knowledge to } \\
\text { successfully perform accounting duties }\end{array}$ & 1.71 & 3.76 \\
\hline $\begin{array}{l}\text { In personnel selection these skills are given at least the } \\
\text { same value as the accounting knowledge. }\end{array}$ & 3.71 & 3.37 \\
\hline $\begin{array}{l}\text { The accounting syllabuses at this university should pay } \\
\text { attention to work place requirements. }\end{array}$ & 4.43 & 3.61 \\
\hline $\begin{array}{l}\text { This university when designing accounting syllabuses, } \\
\text { do pay attention to work place requirements. }\end{array}$ & 4.29 & 3.46 \\
\hline $\begin{array}{l}\text { The development of these skills should be integrated } \\
\text { into all subject areas in the accounting curriculum. }\end{array}$ & 4.00 & 3.73 \\
\hline $\begin{array}{l}\text { It is better to achieve skills development by additional } \\
\text { specific courses. }\end{array}$ & 2.71 & 3.41 \\
\hline $\begin{array}{l}\text { By using certain teaching methods, it is possible to } \\
\text { develop skills simultaneously with the teaching of } \\
\text { technical accounting knowledge. }\end{array}$ & 4.14 & \\
\hline $\begin{array}{l}\text { The development of these skills is at the cost of time for } \\
\text { technical knowledge coverage. }\end{array}$ & 3.00 & \\
\hline
\end{tabular}


Table 6: Skewness and Kurtosis measures

\begin{tabular}{|l|r|r|r|r|r|r|}
\hline & CO-Ss & T-W-Ss & PR-Ss & T-M-Ss & IN-T-Ss & Other-SVKs \\
\hline N Valid & 41.00 & 41.00 & 41.00 & 41.00 & 41.00 & 41.00 \\
\multicolumn{1}{|c|}{ Missing } & 0.00 & 0.00 & 0.00 & 0.00 & 0.00 & 0.00 \\
Mean & 3.80 & 3.90 & 3.80 & 3.89 & 3.49 & 3.74 \\
Skewness & -1.75 & -1.03 & -0.46 & -0.25 & 0.61 & -1.40 \\
Std. Error of Skewness & 0.37 & 0.37 & 0.37 & 0.37 & 0.37 & 0.37 \\
Kurtosis & 5.30 & 0.88 & 0.29 & -0.76 & -0.45 & 3.66 \\
Std. Error of Kurtosis & 0.72 & 0.72 & 0.72 & 0.72 & 0.72 & 0.72 \\
\hline
\end{tabular}

$\mathrm{N}=$ Number

$\mathrm{CO}-\mathrm{Ss}=$ Communication skills

$\mathrm{T}-\mathrm{W}$-Ss $=$ Team working skills

PR-Ss = Problem solving skills

T-M-Ss = Time management skills

IN-T-Ss = Information technology skills

Other-SVKs = Other values, knowledge and skills 
Table 7: Mean for problem solving skills set, time management skills set and information technology skills set Independent sample t-test

\begin{tabular}{|ll|c|r|r|r|}
\hline & PLY & N & \multicolumn{1}{|c|}{ Mean } & Std. Deviation & Std. Error Mean \\
\hline Problem solving & Yes & 30.00 & 3.83 & 0.63 & 0.11 \\
skills & No & 11.00 & 3.75 & 0.77 & 0.23 \\
\hline Time management & Yes & 30.00 & 3.81 & 0.73 & 0.13 \\
skills & No & 11.00 & 4.09 & 0.80 & 0.24 \\
\hline Information & Yes & 30.00 & 3.52 & 0.85 & 0.15 \\
technology skills & No & 11.00 & 3.41 & 0.63 & 0.19 \\
\hline
\end{tabular}

$\mathrm{N}=$ Number

PLY = Placement year 
Table 8: Independent sample t-test for problem solving skills set, time management skills set and information technology skills set

\begin{tabular}{|c|c|c|c|c|c|c|c|c|c|c|}
\hline & \multicolumn{2}{|c|}{$\begin{array}{c}\text { Levene's Test for } \\
\text { Equality of } \\
\text { Variances } \\
\end{array}$} & \multicolumn{7}{|c|}{ t-test for Equality of Means } \\
\hline & & \multirow[b]{2}{*}{$\mathrm{F}$} & \multirow[b]{2}{*}{ Sig. } & \multirow[b]{2}{*}{$\mathrm{t}$} & \multirow[b]{2}{*}{ df } & \multirow{2}{*}{$\begin{array}{l}\text { Sig. (2- } \\
\text { tailed) }\end{array}$} & \multirow{2}{*}{$\begin{array}{c}\text { Mean } \\
\text { Difference }\end{array}$} & \multirow{2}{*}{$\begin{array}{c}\text { Std. Error } \\
\text { Difference }\end{array}$} & \multicolumn{2}{|c|}{$\begin{array}{l}95 \% \text { Confidence } \\
\text { Interval of the } \\
\text { Difference }\end{array}$} \\
\hline & & & & & & & & & Lower & Upper \\
\hline PRSs & $\begin{array}{l}\text { Equal variances assumed } \\
\text { Equal variances not assumed }\end{array}$ & 0.44 & 0.51 & $\begin{array}{l}0.32 \\
0.29\end{array}$ & $\begin{array}{l}39.00 \\
15.08\end{array}$ & $\begin{array}{l}0.75 \\
0.78\end{array}$ & $\begin{array}{l}0.08 \\
0.08\end{array}$ & $\begin{array}{l}0.24 \\
0.26\end{array}$ & $\begin{array}{l}-0.40 \\
-0.48 \\
\end{array}$ & $\begin{array}{l}0.55 \\
0.63\end{array}$ \\
\hline TMSs & $\begin{array}{l}\text { Equal variances assumed } \\
\text { Equal variances not assumed }\end{array}$ & 0.08 & 0.79 & $\begin{array}{l}-1.06 \\
-1.01\end{array}$ & $\begin{array}{l}39.00 \\
16.45\end{array}$ & $\begin{array}{l}0.30 \\
0.33\end{array}$ & $\begin{array}{l}-0.28 \\
-0.28\end{array}$ & $\begin{array}{l}0.26 \\
0.28\end{array}$ & $\begin{array}{l}-0.81 \\
-0.87\end{array}$ & $\begin{array}{l}0.26 \\
0.31\end{array}$ \\
\hline INTSs & $\begin{array}{l}\text { Equal variances assumed } \\
\text { Equal variances not assumed }\end{array}$ & 1.07 & 0.31 & $\begin{array}{l}0.38 \\
0.44\end{array}$ & $\begin{array}{l}39.00 \\
24.17\end{array}$ & $\begin{array}{l}0.70 \\
0.66\end{array}$ & $\begin{array}{l}0.11 \\
0.11\end{array}$ & $\begin{array}{l}0.28 \\
0.24\end{array}$ & $\begin{array}{r}-0.46 \\
-0.40\end{array}$ & $\begin{array}{l}0.67 \\
0.61\end{array}$ \\
\hline $\begin{array}{l}\text { Sig }=\text { Sig } \\
\text { T = test } \\
\text { Df- Degre } \\
\text { PRSs = P } \\
\text { TMSs = 7 } \\
\text { INTSs = }\end{array}$ & $\begin{array}{l}\text { icance } \\
\text { of freedom } \\
\text { olem solving skills } \\
\text { ne management skills } \\
\text { ormation technology skills }\end{array}$ & & & & & & & & & \\
\hline
\end{tabular}


Table 9: mean ranks using Mann-Whitney U Test

\begin{tabular}{|ll|r|r|r|}
\hline & Placement year & N & Mean Rank & Sum of Ranks \\
\hline Communication skills & Yes & 30 & 21.17 & 635.00 \\
& No & 11 & 20.55 & 226.00 \\
& Total & 41 & & \\
Team working skills & Yes & 30 & 20.92 & 627.50 \\
& No & 11 & 21.23 & 233.50 \\
& Total & 41 & & \\
Other values, knowledge & Yes & 30 & 18.95 & 568.50 \\
and skills & No & 11 & 26.59 & 292.50 \\
& Total & 41 & & \\
& & & \\
\end{tabular}

$\mathrm{N}=$ Number 
Table 10: Test Statistics Sig. value (b) using Mann-Whitney U Test

\begin{tabular}{|c|c|c|c|}
\hline & Communication skills & Team working skills & $\begin{array}{l}\text { Other knowledge value } \\
\text { and skills }\end{array}$ \\
\hline Mann-Whitney U & 160.00 & 162.50 & 103.50 \\
\hline Wilcoxon W & 226.00 & 627.50 & 568.50 \\
\hline $\mathrm{Z}$ & -0.15 & -0.074 & -1.83 \\
\hline Asymp. Sig. (2-tailed) & 0.88 & 0.94 & 0.07 \\
\hline Exact Sig. [2*(1-tailed Sig.)] & $.896(a)$ & $.942(a)$ & $.070(\mathrm{a})$ \\
\hline
\end{tabular}

a Not corrected for ties.

b Grouping Variable: Placement year 